\title{
Restinga lizards (Reptilia: Squamata) at the Imbassaí Preserve on the northern coast of Bahia, Brazil
}

\author{
Danilo Couto-Ferreira ${ }^{1}$, Moacir Santos Tinôco ${ }^{2}$, Magno Lima Travassos de \\ Oliveira $^{3}$, Henrique Colombini Browne-Ribeiro ${ }^{4}$, Cecil Pergentino Fazolato ${ }^{5}$, \\ Ricardo Marques da Silva ${ }^{6}$, Gilvana Santos Barreto ${ }^{7} \&$ Marcelo Alves Dias ${ }^{8}$
}

\author{
1,5,6,7 Graduando em Ciências Biológicas - Universidade Católica do Salvador (UCSal), Av. Prof. Pinto de Aguiar, 2589, 41.740-090, \\ Pituaçu, Salvador-BA, Brasil. \\ ${ }^{2}$ Docente do Instituto de Ciências Naturais e da Saúde da UCSal. PhD Candidate, Biodiversity Management - DICE, Department of \\ Anthropology and Conservation, Marlowe Building, The University of Kent at Canterbury, Kent, CT2 7NZ. \\ ${ }^{3}$ Mestrando em Ecologia e Biomonitoramento - Universidade Federal da Bahia (UFBa), Rua Barão de Jeremoabo, s/n, 40.170-115, \\ Ondina, Salvador-BA, Brasil. \\ ${ }_{2,4}$ M.Sc. em Ecologia e Biomonitoramento - UFBa. \\ ${ }^{8}$ Mestrando em Zoologia - PEDECIBA, Universidad de la República Uruguay. Oficinas Centrales, Av. 18 de Julio 1968, Montevideo, \\ Uruguay. \\ 1,2,3,4,5,6,7,8 Centro de Ecologia e Conservação Animal (ECOA/UCSal); 1,2,4,5,6,7,8 Lacerta Consultoria, Projetos e Assessoria Ambiental Ltda. \\ Email: 1 danilocoutoferreira@gmail.com (corresponding author), ${ }^{2}$ mst8@kent.ac.uk, ${ }^{3}$ magno travassos@hotmail.com, \\ ${ }^{4}$ henriquebrowne@gmail.com, ${ }^{5}$ fazolato.cp@gmail.com, ${ }^{6}$ ricardomarquesdasilva@hotmail.com , ${ }^{7}$ gilvanabarreto@gmail.com, \\ ${ }^{8}$ marceloalvesdias@yahoo.com.br
}

Date of publication (online): 26 August 2011 Date of publication (print): 26 August 2011 ISSN $0974-7907$ (online) | 0974-7893 (print)

\section{Editor: Aaron Bauer}

\section{Manuscript details:}

Ms \# 02800

Received 11 May 2011

Final received 28 June 2011

Finally accepted 01 August 2011

Citation: Couto-Ferreira, D., M.S. Tinôco, M.L.T. de Oliveira, H.C. Browne-Ribeiro, C.P. Fazolato, R.M. da Silva, G.S. Barreto \& M.A. Dias (2011) Restinga lizards (Reptilia: Squamata) at the Imbassaí Preserve on the northern coast of Bahia, Brazil. Journal of Threatened Taxa 3(8): 1990-2000.

Copyright: (c) Danilo Couto-Ferreira, Moacir Santos Tinôco, Magno Lima Travassos de Oliveira, Henrique Colombini Browne-Ribeiro, Cecil Pergentino Fazolato, Ricardo Marques da Silva, Gilvana Santos Barreto \& Marcelo Alves Dias 2011. Creative Commons Attribution 3.0 Unported License. JoTT allows unrestricted use of this article in any medium for non-profit purposes, reproduction and distribution by providing adequate credit to the authors and the source of publication.

For Author Details, Author Contributions and Acknowledgements see end of this article

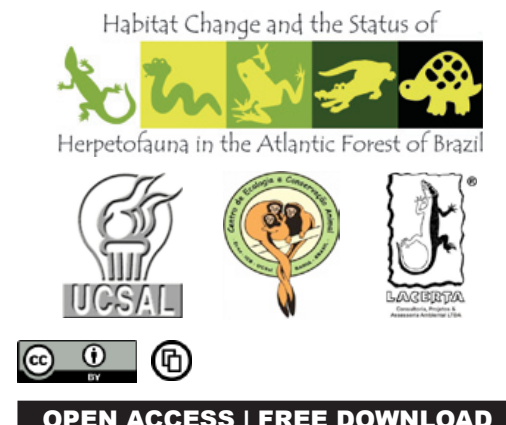

Abstract: This study presents the diversity of lizard species at the Imbassaí Preserve, located in the Mata de São João municipality, on the northern coast of Bahia region, Brazil, with special attention to the threatened and endemic species. We present the main results on richness and abundance, from a long term monitoring program and especially from the period between November 2008 and June 2010. We applied the visual search method associated with pitfall traps and random encounters, on a $200 \mathrm{~m}$ linear transect, in four different vegetation habitats. We detected 26 lizard species, distributed in 19 genera of 10 families. The study reveals a high diversity area for lizards, within the restinga ecosystem along the northern coast line, and therefore contributes to the knowledge of the herpetofauna on the northern coast of the Bahia region, as well as to future management and monitoring programs.

Keywords: Atlantic Forest, herpetofauna, northeast, restinga.

Portuguese Abstract: Este estudo apresenta a diversidade de espécies de lagartos na Reserva Imbassaí, localizada no município de Mata de São João, na região do litoral norte da Bahia, Brasil, com atenção especial para as espécies endêmicas e ameaçadas. Nós apresentamos os principais resultados sobre a riqueza e abundância, a partir de uma programa de monitoramento de longa duração e especialmente do período entre novembro de 2008 e junho de 2010. Nós aplicamos o método da procura visual, associado à armadilhas de direcionamento e queda e encontros ocasionais, ao longo de um transecto linear de $200 \mathrm{~m}$, em quatro diferentes fitofisionomias. Nós detectamos 26 espécies de lagartos, distribuídas entre 19 gêneros e dez famílias. O estudo revela uma área de elevada diversidade de lagartos, em ecossistema de restinga ao longo da linha costeira, e assim contribuindo para o conhecimento sobre a herpetofauna do litoral norte da Bahia, bem como para futuros programas de manejo e monitoramento.

\section{INTRODUCTION}

Squamates are the most speciose clade of reptiles. They comprise 7200 species, and even excluding snakes, there are still 4450 species, which leaves lizards with the greatest number of extant species among living reptile groups (Vitt \& Caldwell 2009). In Brazil there are 308 species (7.11\% of the global diversity). These are distributed in 14 families mainly inhabiting the Atlantic and Amazon forest biomes (Martins \& Molina 2008). 
The Atlantic Forest biome brings together diverse ecosystems, including the rainforest, flooded forests, mangroves, swamps and the coastal sand dune plains, locally known as restinga (Câmara 2003). Even though it is classified as a global biodiversity hotspot, the entire biome and its associated ecosystems suffer from severe habitat loss due to urban growth and other human associated impacts, including tourism, industry and agriculture, mainly on the coastal lands of Brazil (Primack \& Rodrigues 2001; Tabarelli et al. 2003, 2005). Among all of these disturbed areas, the northern coast of Bahia demands special attention for its extent and unique landscape features (Dias \& Rocha 2005; Tinôco et al. 2008, 2010). As a result of this, most of the 20 endangered and endemic Brazilian reptile species, nine of them lizards, occur in the Atlantic Forest, and 13 of these are limited to coastal ecosystems, especially the restinga, (Tabarelli et al. 2003, 2005; Martins \& Molina 2008).

Throughout this region where the restinga is the dominant landscape component, the construction of hotel resorts, highways, residential estates and villages, dating from the early 1960s (Kottak 2006) are contributing to the loss of large tracts of habitat, where the fauna is to some extent, still unknown, especially for those elements for which the actual biodiversity is not well described, as is the case for the herpetofauna (Dias \& Rocha 2005; Tinôco et al. 2008, 2010).

The verified development within the region reflects on the stability of the natural communities, and may be interfering with its natural balance, in such a way that important biodiversity elements may be disappearing or declining. Therefore, this also reflects on the high relevance of such studies, the outcomes of which include the bringing to light of the actual status of the fauna and flora on a long term basis (Tinôco et al. 2008, 2010).

Reptiles are, in the above context, especially well adapted to the restinga environment, first because their physiology allows most taxa to adapt to the low levels of moisture and to the high temperatures (Rocha 2000). However, although some local efforts have been made in the southeast of the country (Rodrigues 2005), little is known about this fauna in the restinga ecosystem of the northern coast of Bahia. This knowledge is therefore, a fundamental tool for taking action to protect this diversity, and to discuss the current status of the taxa described as endemic or threatened to extinction (Dias \& Rocha 2005; Tinôco et al. 2008, 2010).

This overall knowledge is well described in other parts of the country where restinga is present, as in the case of Guriri, in Espírito Santos State (Teixeira 2001), Jurubatiba, in Rio de Janeiro (Rocha et al. 2004) and Juréia, in São Paulo (Marques \& Sazima 2004). These are significant studies conducted over ten years in some cases, but there are no accounts of comparable long term monitoring programs on the coast of Bahia, especially concerning reptiles, and more specifically, lizard species.

Following these assumptions, this study presents the lizard species composition and overall diversity at Imbassaí Preserve, including notes on the use of habitat in four vegetation type habitats, and distinctive contributions to herpetofaunal knowledge, giving special attention to endangered and endemic species.

\section{MATERIALS AND METHODS}

\section{Study site}

The study was conducted in the Imbassaí Preserve, a private preserve, one of a few protected areas within the region that includes the restinga ecosystem, in Mata de São João municipality, on the northern coast of Bahia, in Brazil (Image 1). The northern coast region of the state lies along $220 \mathrm{~km}$ of coastline, all of which incorporates the restinga ecosystem in connection with important patches of rainforest remnants. The study site is also within the borders of the North Coast Environmental Protection Area (NCEPA), locally known as APA ("Area de Proteção Ambiental do Litoral Norte" Decreto No 1.046/1992).

The region is dominated by a tropical climate, with 1,500-2,100 $\mathrm{mm}$ annual rainfall, with greatest precipitation between the months of May and August, and annual air temperature varying along a 23-35 ${ }^{\circ} \mathrm{C}$ gradient (Queiroz 2007). The Imbassaí Preserve $\left(12^{0} 28^{\prime} 43.11^{\prime \prime} \mathrm{S} \& 37^{0} 57^{\prime} 28.64^{\prime \prime} \mathrm{W}\right)$ is part of a more extensive property (138ha) of natural and developed areas, and it is comprised of residential villages, resort hotels, a commercial village, and a natural preserved environmental zone, which represents over $40 \%$ of the entire property, which is preserved as a part of a mitigation plan proposed by the governmental licensing process. 


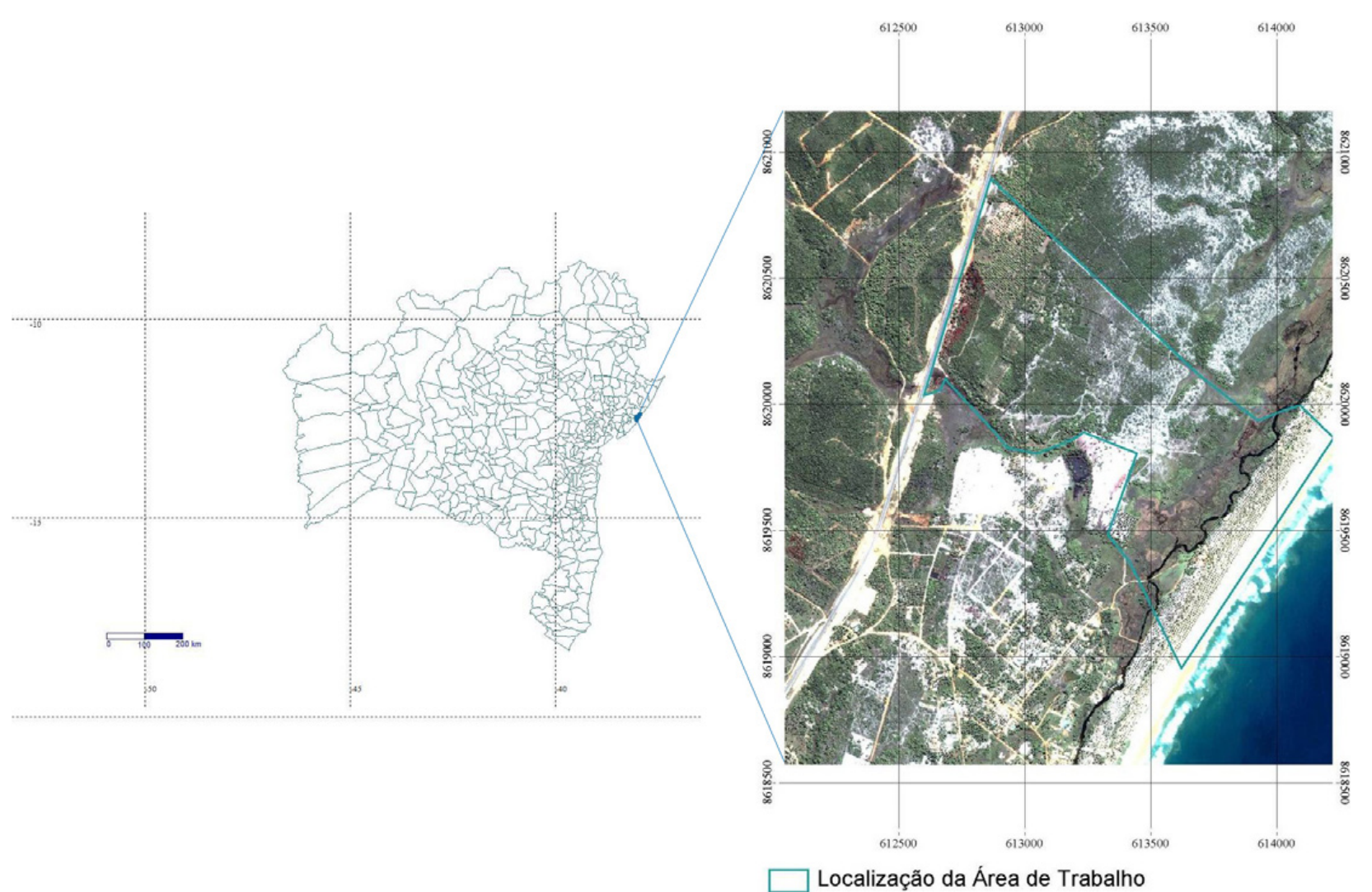

$500 \quad 0 \quad 500 \quad 1000 \mathrm{M}$

Image 1. Study site location - Reserve Imbassaí, northern coast of Bahia, northeast of Brazil. (Map: C.M. Menezes 2008)

The landscape also includes a traditional village and other private properties, which have been left undisturbed nearby. The study site is composed of four dominant vegetation habitat types: herbaceous beach vegetation (BV; Images $2 \mathrm{~A}, \mathrm{~B})$, temporary and permanently flooded zones (HZ; Images $2 \mathrm{~B}, \mathrm{C})$, scrub vegetation $(\mathrm{SV}$; Images $2 \mathrm{D}, \mathrm{E})$ and dry restinga forest (RF; Images 2E,F).

\section{Data collection and analysis}

Six surveys were conducted between November 2008 and June 2010 every two months, including all seasonal variations within a year. Each survey consisted of four simultaneous sample days in all four sampled vegetation type habitats $(\mathrm{BV}, \mathrm{HZ}, \mathrm{SV}$, and $\mathrm{RF})$. Each sampled site, consisted of a linear transect of $200 \mathrm{~m}$, where visual searching technique and pitfall trapping were used. The visual search was conducted by two surveyors for two hour periods.

The six surveys were conducted from $0600 \mathrm{hr}$ to $1800 \mathrm{hr}$, and covered all sample sites, and the four vegetation type habitats, where animals were searched for throughout the 12 daylight hour period during the one year study. All surveys also included a night search in all sampled vegetation type habitats, consisting of visual searching from 1900 to $2100 \mathrm{hr}$. Sample design consisted of the application of two main techniques: (1) the time constrained visual search, consisting of active searching, where all micro habitats and refuges were searched by two experienced surveyors, during two hours, totaling 384 hours effort, and; (2) drift fence pitfall trapping, using two 20 litter buckets, with a $10 \mathrm{~m}$ long and $0.4 \mathrm{~m}$ high black plastic construction sheet fixed with wooden poles. We used 50 such traps, which remained open for four consecutive days, in all four vegetation type habitats; (3) finally, random encounters (RE) were also recorded, and consisted of the record of any animal detected by chance along the transect, and outside of the search hours.

All recorded specimens had their location and habitat type registered, biometric information taken, and were marked (fluorescent elastomer) and released at the point of capture. The study was conducted under permit 03/2009 - NUFAU - IBAMA/BA, for the 

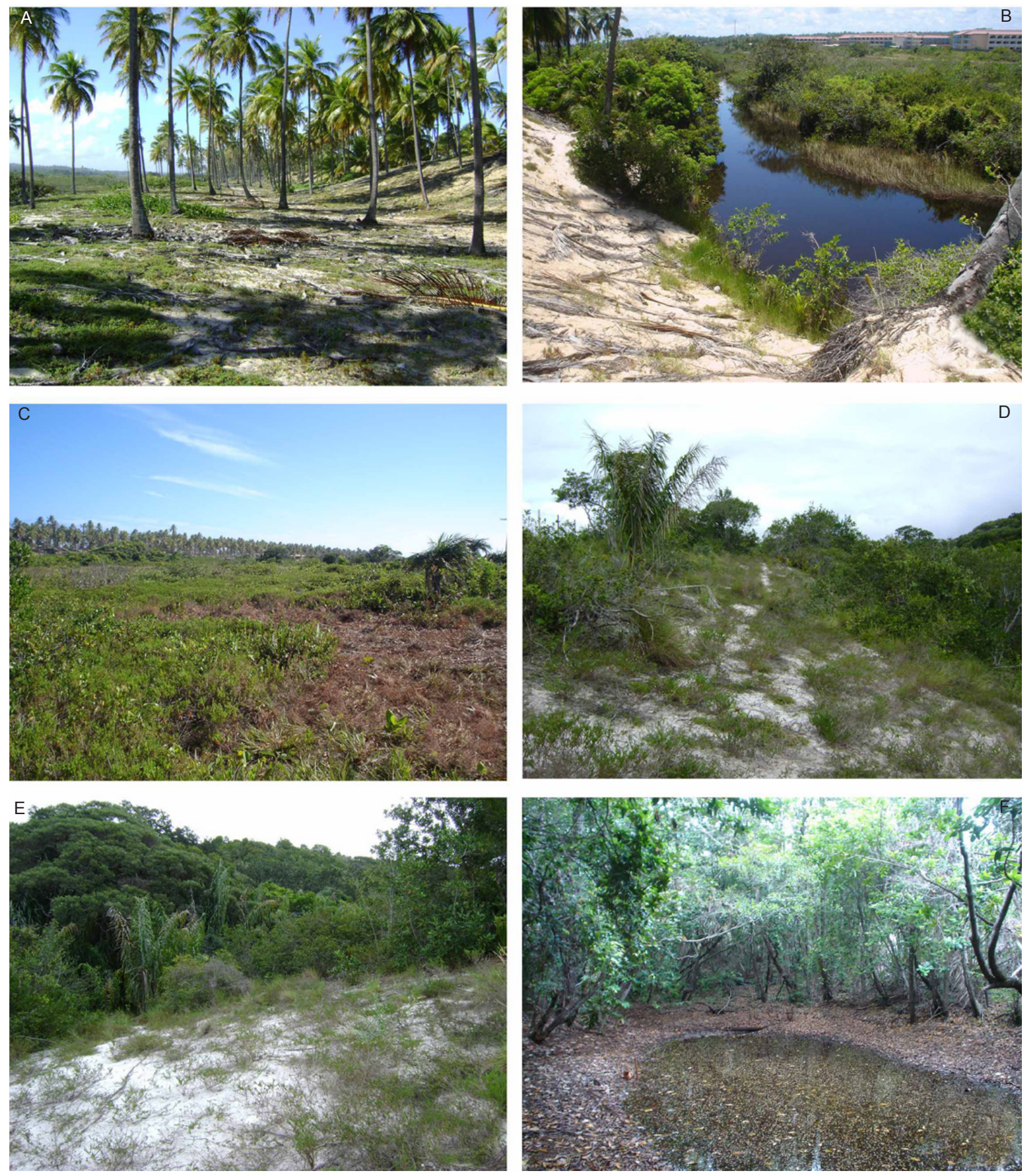

Image 2. Restinga vegetation type at the Reserva Imbassaí, northern coast of Bahia, Brazil

A - Herbaceous beach vegetation; B - Imbassaí river on the border of beach vegetation and the humid vegetation zone;

C - Temporary humid zone flooded; D - Scrub vegetation; E - Transition between the scrubby vegetation and the dry restinga forest; F - Restinga Dry Forest. Photos by D. Couto-Ferreira.

Imbassaí Preserve Long Term Monitoring Program.

General counts are presented, including abundance and richness as the main data summaries. Shannon and Simpson diversity indices were calculated. The choice of these indices takes into account the presence of rare and common species, and therefore gives a broader view of the local lizard diversity.

Species conservation status categories classification (Data Deficient - DD; Least Concern - LC; Vunerable - VU; Endangered - EN) considered the IUCN Red 
List, when listed, otherwise, the national red list was applied. Categories are indicated on the species list table.

\section{RESULTS}

We registered 26 lizard species for the study site, distributed into 19 genera and 10 families: Amphisbaenidae ( $n=3)$, Iguanidae $(n=1)$, Polychrotidae $(\mathrm{n}=2)$, Tropiduridae $(\mathrm{n}=3)$, Gekkonidae $(\mathrm{n}=2)$, Phyllodactylidae $(n=4)$, Sphaerodactylidae $(n=1)$, Teiidae $(n=5)$, Gymnophthalmidae $(n=3)$ e Scincidae $(n=2)$. The most abundant species, in descending order were: Tropidurus hygomi Reinhardt \& Luetken, 1861 ( $\mathrm{n}=1599)$ a local restinga endemic species, Cnemidophorus ocellifer (Spix, 1825) ( $\mathrm{n}=641)$, Coleodactylus meridionalis (Boulenger, 1888) (n=103), Mabuya macrorhyncha Hoge, 1947 ( $\mathrm{n}=69)$, Phyllopezus pollicaris (Spix, 1825) $(\mathrm{n}=46)$, Bogertia lutzae Loveridge, 1941 ( $\mathrm{n}=27)$, Hemidactylus mabouia (Moreau de Jonnès, 1818) $(\mathrm{n}=21)$, Cnemidophorus abaetensis Dias, Rocha \& Vrcibradic, 2002, a local restinga endangered species according to the Brazilian red list $(\mathrm{n}=18)$, Tupinambis merianae (Duméril \& Bibron, 1839) ( $\mathrm{n}=7)$, Iguana iguana (Linnaeus, 1758) $(\mathrm{n}=4)$, Hemidactylus brasilianus (Amaral, 1935) $(\mathrm{n}=4)$, Micrablepharus maximiliani (Reinhardt \& Luetken, 1862) (n=3) Tropidurus hispidus (Spix, 1825) ( $\mathrm{n}=3)$, Anolis ortonii Cope, $1868(\mathrm{n}=3)$, Gymnodactylus darwinii (Gray, 1845) (n=2), Kentropix calcarata Spix, 1825 ( $\mathrm{n}=2)$, Amphisbaena vermicularis Wagler, 1824 ( $\mathrm{n}=2)$, and Amphisbaena alba Linnaeus, 1758, Amphisbaena octostega (Duméril, 1851), Ameiva ameiva (Linnaeus, 1758), Cercosaura ocellata Wagler, 1830, Colobossaura modesta (Reinhardt \& Lütken, 1862), Mabuya agilis (Raddi, 1823), Phyllopezus periosus Rodrigues, 1986, Polychrus acutirostris Spix, 1825 and Tropidurus semitaeniatus (Spix, 1825) (all $\mathrm{n}=1$ ) (Table 1; Images 3-5).

About $59 \%$ of the detected species were using one vegetation type habitat, the other $25 \%$ were recorded using two of those habitats, $3 \%$ used three habitat types, and $11 \%$ were using all four. However, when looking at each vegetation type as a distinct habitat, the humid zones recorded $51 \%$ of the use, the beach vegetation and restinga forest $40 \%$, and the scrub vegetation habitat type $33 \%$ of lizards' richness (Table
Table 1. Lizard species list for the Reserve Imbassaí, restinga ecosystem, northern coast of Bahia, Brazil N - number of individuals; Vegetation type (1 - BV, 2 - HZ, 3 - SV, 4 - RF).

\begin{tabular}{|c|c|c|c|}
\hline Family (Author) / Species (Author) & $\mathbf{N}$ & $\begin{array}{l}\text { Vegetation } \\
\text { type }\end{array}$ & Categ. \\
\hline \multicolumn{4}{|l|}{ Amphisbaenidae Gray, 1825} \\
\hline Amphisbaena alba Linnaeus, 1758 & 1 & 4 & LC \\
\hline $\begin{array}{l}\text { Amphisbaena vermicularis Wagler, } \\
1824\end{array}$ & 2 & 4 & \\
\hline $\begin{array}{l}\text { Amphisbaena octostega (Duméril, } \\
\text { 1851) }\end{array}$ & 1 & 4 & \\
\hline \multicolumn{4}{|l|}{ Iguanidae Oppel, 1811} \\
\hline Iguana iguana (Linnaeus, 1758) & 4 & 1,2 & \\
\hline \multicolumn{4}{|l|}{ Polychrotidae Fitzinger, 1843} \\
\hline Polychrus acutirostris Spix, 1825 & 1 & 2 & \\
\hline Anolis ortonii Cope, 1868 & 3 & 4 & \\
\hline \multicolumn{4}{|l|}{ Tropiduridae Bell, 1843} \\
\hline Tropidurus hispidus (Spix, 1825) & 3 & 3 & \\
\hline $\begin{array}{l}\text { Tropidurus hygomi Reinhardt \& } \\
\text { Lütken, } 1861\end{array}$ & 1599 & $1,2,3,4$ & \\
\hline $\begin{array}{l}\text { Tropidurus semitaeniatus (Spix, } \\
\text { 1825) }\end{array}$ & 2 & 2 & LC \\
\hline \multicolumn{4}{|l|}{ Gekkonidae Gray, 1827} \\
\hline $\begin{array}{l}\text { Hemidactylus mabouia (Moreau de } \\
\text { Jonnès, 1818) }\end{array}$ & 21 & 1,3 & \\
\hline $\begin{array}{l}\text { Hemidactylus brasilianus (Amaral, } \\
\text { 1935) }\end{array}$ & 4 & 2,3 & \\
\hline \multicolumn{4}{|l|}{$\begin{array}{l}\text { Phyllodactylidae Gamble, Bauer, } \\
\text { Greenbaum \& Jackman, } 2008\end{array}$} \\
\hline Bogertia lutzae Loveridge, 1941 & 27 & 2,3 & \\
\hline $\begin{array}{l}\text { Gymnodactylus darwinii (Gray, } \\
\text { 1845) }\end{array}$ & 2 & 1 & \\
\hline $\begin{array}{l}\text { Phyllopezus periosus Rodrigues, } \\
1986\end{array}$ & 1 & 4 & \\
\hline Phyllopezus pollicaris (Spix, 1825) & 46 & 1 & \\
\hline \multicolumn{4}{|l|}{$\begin{array}{l}\text { Sphaerodactylidae Underwood, } \\
1954\end{array}$} \\
\hline $\begin{array}{l}\text { Coleodactylus meridionalis } \\
\text { (Boulenger, 1888) }\end{array}$ & 103 & $2,3,4$ & \\
\hline \multicolumn{4}{|l|}{ Teiidae Gray, 1827} \\
\hline Ameiva ameiva (Linnaeus, 1758) & 1 & 2 & \\
\hline $\begin{array}{l}\text { Cnemidophorus abaetensis Dias, } \\
\text { Rocha \& Vrcibradic, } 2002\end{array}$ & 18 & 3,4 & VU \\
\hline $\begin{array}{l}\text { Cnemidophorus ocellifer (Spix, } \\
\text { 1825) }\end{array}$ & 641 & $1,2,3,4$ & \\
\hline $\begin{array}{l}\text { Tupinambis merianae (Duméril \& } \\
\text { Bibron, 1839) }\end{array}$ & 7 & 2,3 & LC \\
\hline Kentropyx calcarata Spix, 1825 & 2 & 4 & \\
\hline \multicolumn{4}{|l|}{ Gymnophthalmidae Merrem, 1820} \\
\hline Cercosaura ocellata Wagler, 1830 & 1 & 2 & \\
\hline $\begin{array}{l}\text { Colobossaura modesta (Reinhardt \& } \\
\text { Luetken, 1862) }\end{array}$ & 1 & 2 & \\
\hline $\begin{array}{l}\text { Micrablepharus maximiliani } \\
\text { (Reinhardt \& Luetken, 1862) }\end{array}$ & 3 & 1,2 & \\
\hline \multicolumn{4}{|l|}{ Scincidae Gray, 1825} \\
\hline Mabuya macrorhyncha Hoge, 1947 & 69 & $1,2,3,4$ & \\
\hline Mabuya agilis (Raddi, 1823) & 1 & 1 & \\
\hline
\end{tabular}



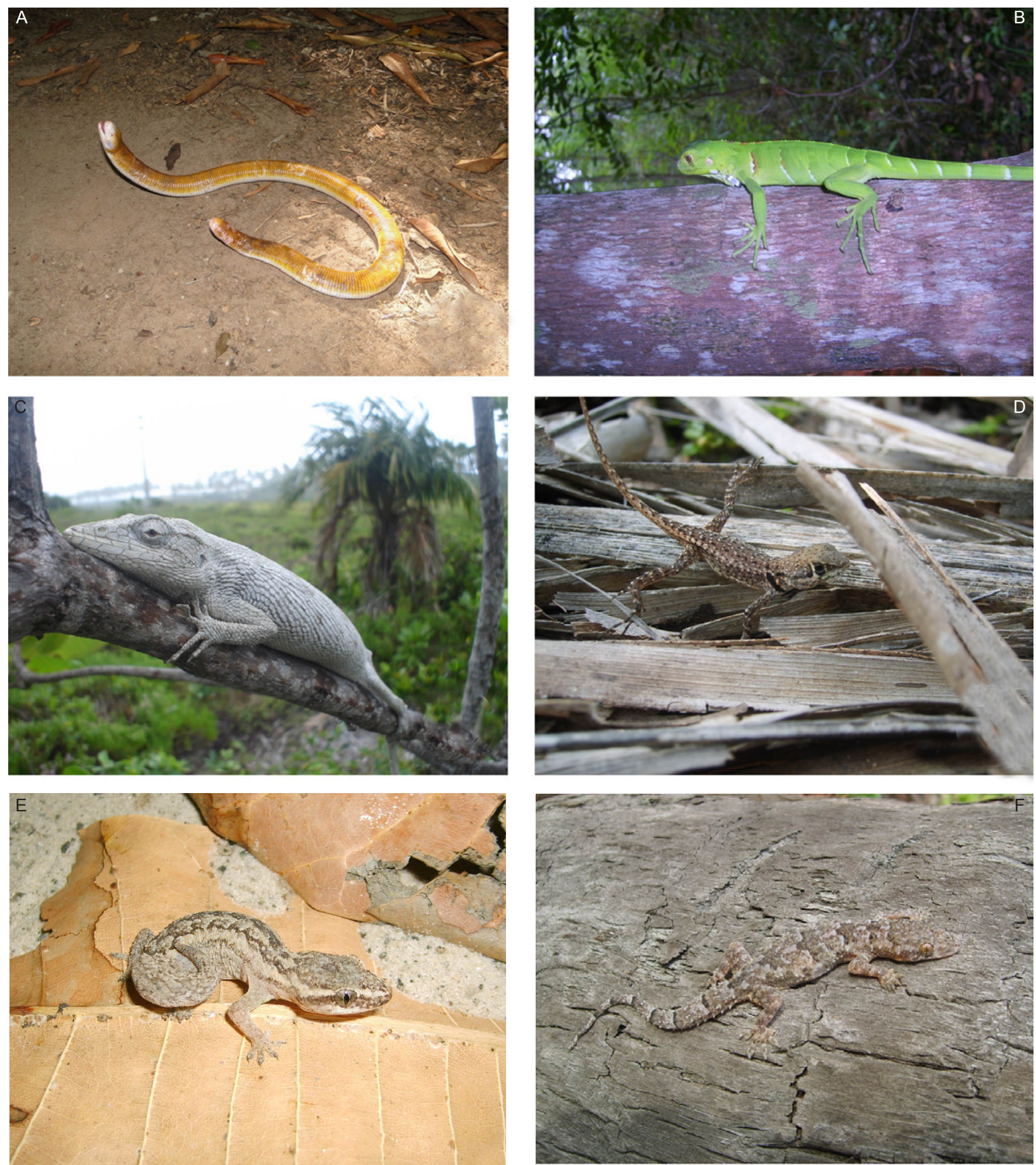

Image 3. Restinga's lizards' species, Reserva Imbassaí, northern coast of Bahia, Brazil

A - Amphisbaena alba (Amphisbaenidae); B - Iguana iguana (Iguanidae); C - Polychrus acutirostris (Polychrotidae);

D - Tropidurus hygomi (Tropiduridae); E - Hemidactylus brasilianus (Gekkonidae); F - Hemidactylus mabouia (Gekkonidae). Photos by R. Marques.

1).

The Imbassaí Preserve lizard diversity is reflected in Shannon and Simpson diversity indices of 2.23 and 0.83 , respectively. The humid vegetation habitat were associated with the highest diversity indices
(Shannon=2.1; Simpson=0.8) followed by dry forest habitat (Shannon=2.11; Simpson=0.79). Beach vegetation had the lowest values, although it showed a high abundance (Shannon=1.37; Simpson=0.62), preceded by the scrub vegetation type habitat 

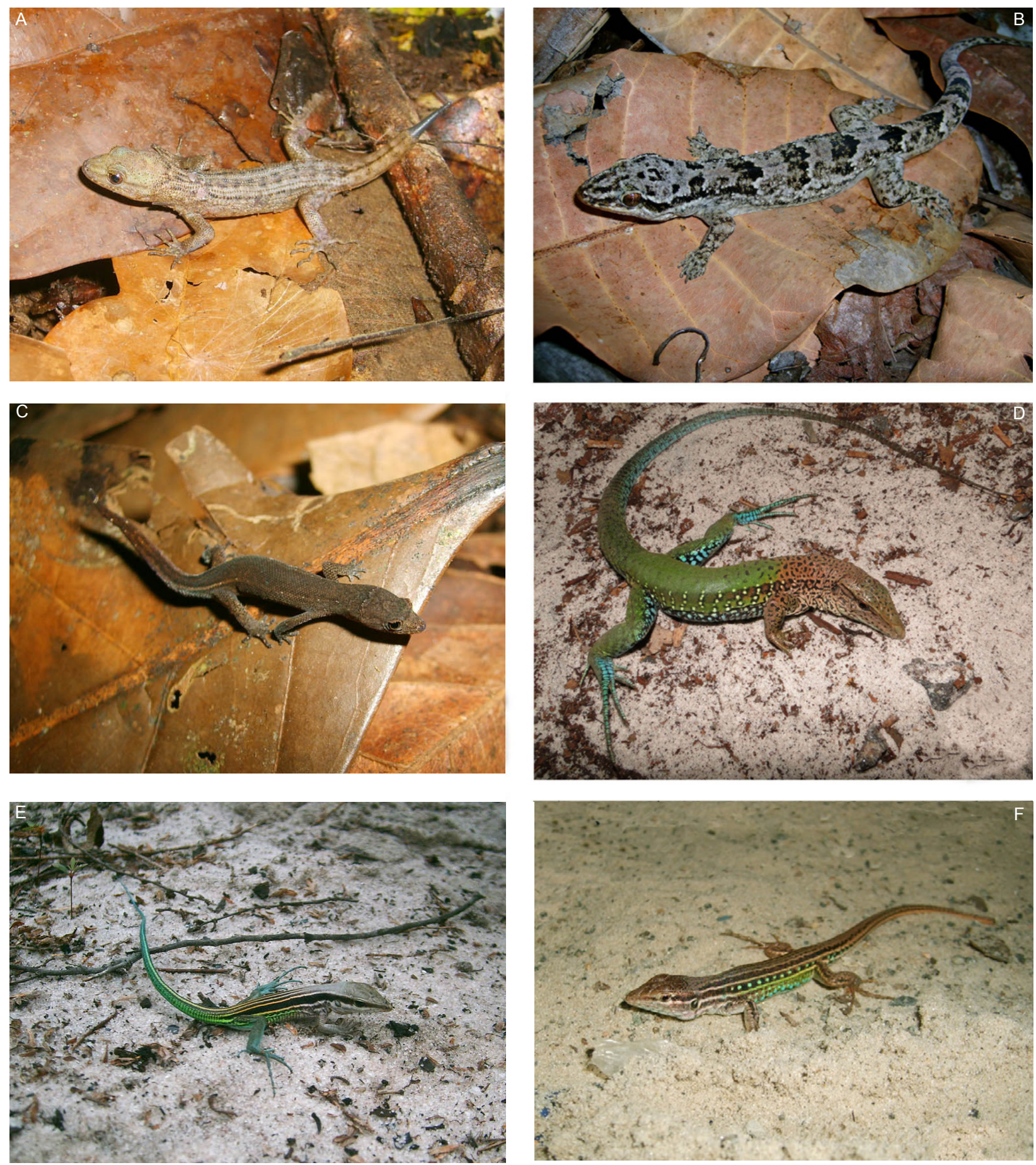

Image 4. Restinga's lizards' species, Reserva Imbassaí, northern coast of Bahia, Brazil

A - Gymnodactylus darwinii (Phyllodactylidae); B - Phyllopezus periosus (Phyllodactylidae); C - Coleodactylus meridionalis (Sphaerodactylidae); D - Ameiva ameiva (Teiidae); E - Cnemidophorus abaetensis (Teiidae); F - Cnemidophorus ocellifer (Teiidae). Photos by R. Marques.

(Shannon=1.41; Simpson=0.63). Despite differences, all vegetation type habitats supported relatively high diversity levels.

\section{DISCUSSION AND CONCLUSIONS}

When we consider the Brazilian list of reptile species (Bérnils 2010), the study recorded nearly $11 \%$ of Brazilian lizard diversity. Some species had 

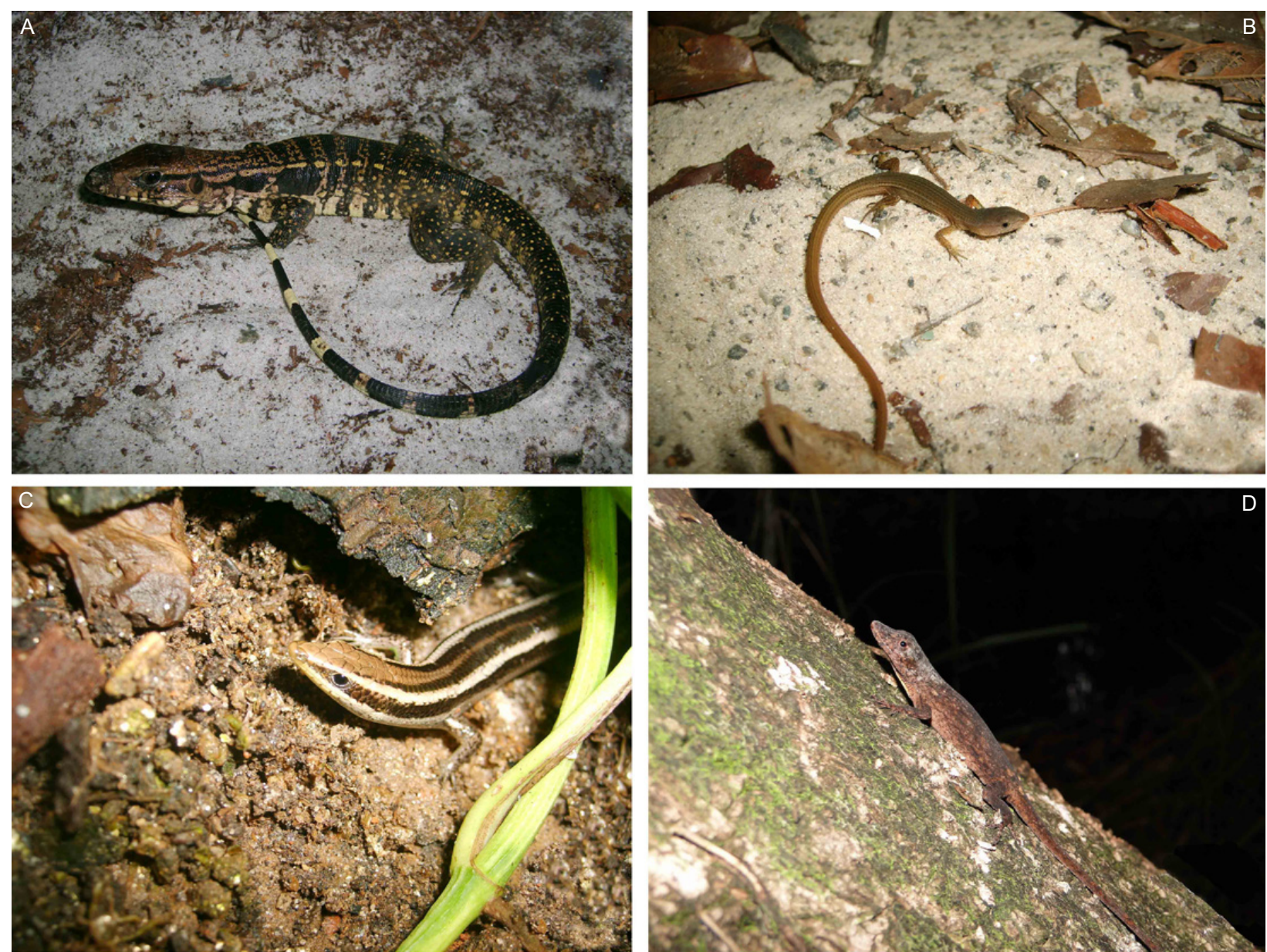

Image 5. Restinga's lizards' species, Reserva Imbassaí, northern coast of Bahia, Brazil

A - Tupinambis merianae (Teiidae); B - Cercosaura ocellata (Gymnophthalmidae); C - Mabuya macrorhyncha (Scincidae); D - Anolis ortonii (Polychrotidae). Photos by R. Marques.

been undetected in previous studies, and some of these had been recorded earlier in the Caatinga and Cerrado biomes at the Atlantic Forest biome's border and adjacent to the restinga ecosystem. These include: Tupinambis merianae and Phyllopezus periosus (Vanzolini et al. 1980; Rodrigues 2003; IUCN 2010).

Previous long term studies in large areas concerning the importance of lizard species in other biomes enhance the relevance of the restinga ecosystem for understanding lizard diversity in Brazil. Vitt et al. (2008) detected 35 species on the Adolpho Ducke Preserve (Amazon), that study was conducted in a 10,000ha area (72 times larger than the Imbassai Preserve) and Colli et al. (2002) found 34 species within five municipalities in the Cerrado biome. Here, we present a small, but interesting portion of lizard diversity when compared to those studies, considering just a small fraction of the entire restinga's ecosystem.

Studies on the Atlantic Forest and associated restinga ecosystem herpetofauna, most of which were conducted in the southeastern region of Brazil, are not as extensive as those mentioned above, in the Amazon and the Cerrado. Teixeira (2001) recorded eight lizards species in a 12-month survey in Espírito Santo State, Marques \& Sazima (2004) detected nine lizards species in a three-year survey, Rocha et al. (2004) recorded eight species in the Jurubatiba restinga habitats; Carvalho et al. (2007) registered 12 species for Marambaia Island (7,700 ha), off the coast of the Rio de Janeiro State, and the Centro de Ecologia e Conservação Animal (ECOA 2010) reported 19 lizard species in a seven-year monitoring program, in the Parque Metropolitano de Pituaçu (Salvador, Bahia, Brazil), urban Atlantic Forest remnant ( $\sim 400$ ha). Given these figures, and noting that the studies 
are not directly comparable, it is clear that the present study reports an important contribution to the overall restinga lizard fauna and adds relevance to the studies mentioned above.

Dias \& Rocha (2005) in a study in the same region as this (covering three different localities), and also including another three localities on the south coast of Bahia, recorded 23 lizard species. However, some of the species recorded here, were not registered in that study, such as, Amphisbaena vermicularis, Amphisbaena octostega, Polychrus acutirostris, Anolis ortonii, Tropidurus hispidus, Tropidurus semitaeniatus, Hemidactylus brasilianus, Gymnodactylus darwinii, Phyllopezus periosus, Phyllopezus pollicaris, Tupinambis merianae and Colobossaura modesta.

Though using different sample designs and time spans, these studies place into context the contribution of the Bahian northern coast to the overall lizard diversity in Brazil. Moreover, this clearly indicates that this is a highly significant region for the conservation of lizards, as it brings together elements (lizard species) from three of the four major biomes: Atlantic Forest, Caatinga and Cerrado, indicating its high biological importance, especially when considering endangered and endemic species.

The Bahian Sand Dune Lizard Cnemidophorus abaetensis and the Sand Dune Lava Lizard Tropidurus hygomi are both endemic to this restinga ecosystem in Bahia (Dias \& Rocha 2005; Tinôco et al. 2010). The first is listed as endangered on the Brazilian red list (Martins \& Molina 2008), and is of high relevance to this study, due to the gap of information concerning their actual conservation status within the region. This could, in some cases, stifle appropriate management policies by public authorities, justified by the lack of consistent published results. These lizards are critically restricted to the scrub and beach vegetation habitats, and therefore more vulnerable to restinga disturbance from the Capital City Salvador to the northern border of the State of Sergipe (Image 4E). Understanding of habitat use may represent an important tool for their conservation in a highly disturbed landscape.

The Bahian Sand Dune lizard and the Sand Dune Lava lizard are among the five Brazilian lizard species with geographical distributions restricted to the coastal restinga. The first one is also listed as Vulnerable in the Brazilian Red List of Threatened Species (Martins \&
Molina 2008). However, the other three species found here, are listed on the IUCN Red List, Amphisbaena alba, Tropidurus semitaeniatus, and the presumably introduced Tupinambis merianae, all under the Least Concern category (IUCN 2010). Tropidurus hygomi although in high abundance, is endemic to the region, occurs mostly on the beach vegetation dunes, and is thus highly vulnerable although it is not listed in any of the categories or lists.

In this study, the distribution of the Bahian Sand Dunes Lizard Cnemidophorus abaetensis was concentrated mainly in the scrub vegetation and the dry forest habitats as suggested by Tinôco et al. (2010). That possibly indicates an important threat to the species' conservation, as local legislation designates all scrub vegetation as development sites, and along the entire northern coast most of the scrub vegetation habitat is being destroyed or degraded for the construction of large hotel resorts and residential estates (Tinôco et al. 2010). These may lead to major gaps in the taxon's distribution and thereby compromise its long term survival within the region. We believe that a combination of a management plan for the entire ecosystem, the establishment of protected areas linked by fauna corridors which can allow the preservation of the major vegetation type habitats and in accordance with the environmental public policies, may result in a better perspective for the conservation of this and the local populations of other taxa.

Our surveys recovered 93.1\% (excepting only Tupinambis teguixin (Linnaeus, 1758) and Amphisbaena nigricauda (Gans, 1966)) of the known lizard diversity for the northern coast of the state of Bahia, representing $11.2 \%$ of Brazilian lizard biodiversity. This results in a high diversity index, especially for the dry forest and aquatic vegetation habitats, which are already protected by Brazilian and state legislation, and reveals, in a highly disturbed ecosystem, threatened, endemic, introduced, and new records for taxa such as the Sand Dune Lava Lizard Tropidurus hygomi and the Bahian Sand Dune Whiptail Cnemidophorus abaetensis, among four other threatened species.

This study contributes 13 new species records for the region, filling some distribution gaps on the northern coast of Bahia for endangered or endemic species, giving important support for the development of a management plan and conservation actions to protect 
lizards, particularly endemic and endangered species on the northern coast of Bahia. It indicates a relevant diversity index for four vegetation type habitats, apart from dry forest and aquatic vegetation habitats, which are already covered by protective legislation. Finally, these important contributions call for action and new policies providing real protection for the high lizard diversity of the Atlantic Forest ecosystem.

\section{REFERENCES}

Bérnils, R.S. (org.). (2010). Brazilian reptiles - List of species. Sociedade Brasileira de Herpetologia. <http://www. sbherpetologia.org.br/>. On-line version dated 27 May 2010.

Câmara, I.G. (2003). Brief history of conservation in the Atlantic forest, pp. 31-42. In: Galindo-Leal, C. \& I.G. Câmara (eds.). The Atlantic Forest of South America: Biodiversity Status, Threats, and Outlook. Center for Applied Biodiversity Science and Island Press, Washington. D.C.

Carvalho, A.L.G., A.F.B. Araújo, H.R. Silva (2007). Lagartos da Marambaia, um remanescente insular de restinga e Floresta Atlântica no estado do Rio de Janeiro, Brasil. Biota Neotropica 7(1): 221-226.

Colli, G.R., R.P. Bastos \& A.F.B. Araújo (2002). The character and dynamics of the Cerrado herpetofauna, pp. 223-241. In: Oliveira, P.S. \& R.J. Marquis (eds.). The Cerrados of Brazil: Ecology and Natural History of a Neotropical Savanna. Columbia University Press, New York.

Dias, E.J.R. \& C.F.D. Rocha (2005). Os répteis nas restingas do Estado da Bahia: pesquisa e ações para a sua conservação. Instituto Biotemas, Rio de Janeiro, 36pp.

ECOA (2010). Animais e plantas do Parque Metropolitano de Pituaçu - Lista de Espécies. Centro de Ecologia e Conservação Animal (ECOA). <http://www.ucsal.br/ pesquisa/ecoa/pesq_apresentacao.asp.> On-line version dated 15 September 2010.

IUCN (2010). IUCN Red List of Threatened Species. Version 2010.4. <www.iucnredlist.org>. Downloaded on 30 December 2010.

Kottak, C.P. (2006). Assault on Paradise - The Globalization of A Little Community in Brazil. McGraw Hill, Fourth Edition, Boston, 221pp.

Marques, O.A.V. \& I. Sazima (2004). História natural dos répteis da Estação Ecológica Juréia-Itatins, pp. 257-277. In: O.A.V. Marques \& W. Dulepa (eds.). Estação Ecológica Juréia-Itatins. Ambientes Físico, Flora e Fauna. Holos, Ribeirão Preto, 384pp.

Martins, M. \& F.B. Molina (2008). Panorama Geral dos Répteis Ameaçados do Brasil, pp. 327-376. In: Machado,
A., G. Drummond \& A. Paglia (eds.). Livro Vermelho da Fauna Brasileira Ameaçada de Extinção. Ministério do Meio Ambiente, Fundação Biodiversitas, Brasília/DF, 1420pp.

Primack, R.B. \& E. Rodrigues (2001). Biologia da Conservação. Editora Planta, Londrina/PR, 328pp.

Queiroz, E.P. (2007). Levantamento florístico e georreferenciamento das espécies com potencial econômico e ecológico em restinga de Mata de São João, Bahia, Brasil. Biotemas 20(4): 41-47.

Rocha, C.F.D. (2000). Biogeografia de répteis de restinga: distribuição, ocorrência e endemismo, pp. 99-116. In: Esteves, F.A. \& L.D. Lacerda (eds.). Ecologia de restingas e lagoas costeiras. Macaé/RJ, NUPEM/UFRJ, 446pp.

Rocha, C.F.D., M. Van-Sluys, D. Vrcibradic, F.H. Hatano, C.A. Galdino, M. Cunha-Barros \& M.C. Kieffer (2004). A comunidade de répteis da restinga de Jurubatiba, pp. 179-198. In: Rocha, C.F.D., F.A. Esteves \& F.R. Scarno (orgs.). Pesquisas ecológicas de longa duração na restinga de Jurubatiba: ecologia, história natural e conservação. RiMa Editora, São Carlos, 374pp.

Rodrigues, M.T. (2005). Conservação dos répteis brasileiros: os desafios para um país megadiverso. Megadiversidade, 1(1): 87-94.

Rodrigues, M.T. (2003). Herpetofauna da Caatinga, pp. 181236. In: Leal, I.R. M. Tabarelli \& J.M.C. Silva (eds.). Ecologia e conservação da Caatinga. Editora Universitária, Universidade Federal de Pernambuco, Recife, Brasil.

Tabarelli, M., L.P. Pinto, J.M.C. Silva \& C.M.R. Costa (2003). The Atlantic Forest of Brazil: endangered species and conservation planning, pp. 86-94. In: Galindo-Leal, C. \& I.G. Câmara (eds.). The Atlantic Forest of South America: biodiversity status, threats, and outlook. Center for Applied Biodiversity Science e Island Press, Washington. D.C.

Tabarelli, M., L.P. Pinto, J.M.C. Silva, M.M. Hirota \& L.C. Bedê (2005). Desafios e oportunidades para a conservação da biodiversidade na Mata Atlântica brasileira. Megadiversidade 1(1): 133-138.

Teixeira, R.L. (2001). Comunidade de lagartos da restinga de Guriri, São Mateus, ES, Sudeste do Brasil. Atlântica, Rio Grande 23: 77-84.

Tinôco, M.S., H.C. Browne-Ribeiro, R. Cerqueira, M.A. Dias \& I.A. Nascimento (2008). Habitat change and the conservation of amphibians in the Atlantic Forest in Bahia, Brazil. Froglog, IUCN/Amphibian Specialist Group 89: $1-3$.

Tinôco, M.S., H.C. Browne-Ribeiro \& M.A. Dias (2010). The Bahian Sand Dunes Whiptail Lizard Cnemidophorus abaetensis Dias, Rocha \& Vrcibradic 2002 (Reptilia, Scleroglossa, Teiidae), geographic distribution and habitat use in Bahia, Brazil. Herpetologicall Bulletin, 111: 19-24.

Vanzolini, P.E., A.M.M. Ramos-Costa \& L.J. Vitt (1980). Répteis das Caatingas. Academia Brasileira de Ciências, 
Rio de Janeiro.

Vitt, L.J., W.E. Magnusson, T.C. Ávila-Pires \& A.P. Lima (2008). Guide to the Lizards of Reserva Adolpho Ducke, Central Amazonia. Átterna Design Editorial, Manaus/AM, 176pp.

Vitt, L.J. \& Caldwell, J.P. (2009). Herpetology. Academic Press. $3^{\text {rd }}$ Edition, Burlington, 713pp.

\section{Author Details}

DANILO COUTO-FERREIRA Biological Sciences undergraduate student and junior researcher at the Centro de Ecologia e Conservação Animal (ECOA), Universidade Católica do Salvador (UCSAL). MoaciR SAntos Tinôco Centro de Ecologia e Conservação Animal (ECOA) co-ordinator. Biodiversity Management PhD Candidate at the Durrell Institute for Conservation and Ecology, School of Anthropology and Conservation, University de Kent. Magno LimA Travassos de OliveIRA MSc in Ecology and Biomonitoring at the Universidade Federal da Bahia (UFBA). Contributing researcher at the Centro de Ecologia e Conservação Animal (ECOA), Universidade Católica do Salvador (UCSAL). Henrique Colombini BrowneRIBEIRO MSc in Ecology and Biomonitoring at the Universidade Federal da Bahia (UFBA) Contributing researcher at the Centro de Ecologia e Conservação Animal (ECOA), Universidade Católica do Salvador (UCSAL). Cecil Pergentino Fazolato Biological Sciences undergraduate student and junior researcher at the Centro de Ecologia e Conservação Animal (ECOA), Universidade Católica do Salvador (UCSAL). RICARDO MARQUES DA SILVA Biological Sciences undergraduate student and junior researcher at the Centro de Ecologia e Conservação Animal (ECOA), Universidade Católica do Salvador (UCSAL). GILvana SANTOS BARRETO Biological Sciences undergraduate student and junior researcher at the Centro de Ecologia e Conservação Animal (ECOA), Universidade Católica do Salvador (UCSAL). Marcelo Alves Dias M.Sc. in Zoology at the Programa de Desarrollo de las Ciencias Básicas (PEDECIBA), da Universidad de la RepublicaUruguay. Contributing researcher at the Centro de Ecologia e Conservação Animal (ECOA), Universidade Católica do Salvador (UCSAL).

Author Contribution: All authors are members of the Long Term Restinga Herpetofauna Management and Monitoring Program, and have contributed to field work sampling in all surveys and the development of the current paper.

Acknowledgments: We thank the Long Term North East of Bahia Herpetofauna Program and the "Habitat Change and the Status of the Herpetofauna in the Atlantic Forest of Brazil" Project, of the Durrell Institute of Conservation and Ecology at the University of Kent, UK, the Centro de Ecologia e Conservação Animal (ECOA) - Universidade Católica do Salvador (UCSal) in Bahia, Brazil, the Lacerta Consultoria, Projetos e Assessoria Ambiental Ltda and the Reserva Imbassaí in Mata de São João, Bahia, for all their support and for the opportunity to develop this study. 